\title{
Do Interest Rates Affect the Exchange Rate Under Capital Controls? An event study of Iceland's experience with capital controls
}

\author{
Ágúst Arnórsson and Gylfi Zoega ${ }^{*_{1}}$
}

\begin{abstract}
Ágrip
Við könnum reynslu Íslands af fjármagnshöftum með áherslu á áhrif vaxtabreytinga á gengi krónunnar frá 2009 til 2015. Niðurstöður benda til pess að áhrif vaxtabreytinga einskorðist við árið 2009 en pá var eftirlit með fjármagnshöftum lítið. Ekki er unnt að finna marktæk áhrif vaxtabreytinga eftir að eftirlit með fjármagnshöftum var eflt í nóvember 2009. Taka verður fram að pessar niðurstöður byggja á peim varkáru breytingum vaxta sem urðu á pessum árum. Jafnframt er ljóst að vextir hafa önnur áhrif en á gengi, t.d. á heildareftirspurn og launapróun.
\end{abstract}

\begin{abstract}
We study Iceland's experience with capital controls, in particular whether changes in the central bank's policy rate affected the exchange rate under the capital control regime from 2009 to 2015.We find that both actual changes and unexpected changes in interest rates may have affected the exchange rate when the year 2009 is included in a sample that ends in August of 2015, but not when it is excluded. This early period was characterized by lax capital controls until November of 2009. It follows that, based on the experience of the moderate changes of interest rates observed in the data, changes in interest rates may affect the exchange rate when capital controls are not effectively enforced but will have a small, if any, effect when they are enforced. It should be noted that the results are based on the experience of moderate interest rate changes during this period. Moreover, interest rates affect other variables, such as aggregate demand and the rate of wage inflation.
\end{abstract}

JEL flokkun: G01, E42, E52, E58

Lykilord: Financial crises, capital controls, policy rates, exchange rates.

${ }^{1}$ Department of Economics, University of Iceland, 101 Reykjavik, Iceland. *Corresponding author: Gylfi Zoega, Department of Economics, University of Iceland, 101 Reykjavik, Iceland. Email: gz@hi.is, Tel. +354 525 5239. Gylfi Zoega is an external member of the Central Bank of Iceland's Monetary Policy Committee. The opinions and results described in this paper are his opinions and do not reflect those of other members of the MPC.

This work was supported by the Icelandic Research Fund (IRF - grant number 130551-052) and the University of Iceland Research Fund. The authors would like to thank two anonymous referees for useful comments.

This work is licensed under a Creative Commons Attribution 4.0 License. 


\section{Introduction}

The Icelandic parliament introduced capital controls on 29 November 2008 following a massive blow to the country's financial system in October the same year. Before and after the financial crisis, the Icelandic economy had capital outflows that followed years of strong inflows in the form of local banks borrowing in international capital markets to finance foreign direct investment and the takeover of domestic companies, and also a carry trade carried out mostly by foreign speculators.

In order to curb the outflow of capital, the Central Bank of Iceland raised its policy rate to $15.5 \%$ in the spring of 2008 , hoping that a higher return on domestic assets might dissuade foreign owners from withdrawing their domestic investment and converting kronur (ISK) into foreign currency. Raising nominal interest rates to such high levels, on the other hand, might be taken as a sign of desperation by foreign investors, not to mention the adverse effect a high interest rate would have on the liquidity position and even solvency position of domestic enterprises. The alternative of allowing the exchange rate to fall would, however, have had even greater adverse effects on these balance sheets due to the prevalence of foreign-currency loans. However, the interest rate increases did not stem the outflow of capital, as the carry trade unraveled and the exchange rate fell and eventually collapsed in September. Due to heavy borrowing in foreign currencies by the Icelandic business sector, the fall in the exchange rate lead the sector into technical bankruptcy, while a modern bank run (the inability of banks to borrow from other banks) triggered the downfall of the commercial banks, which could no longer roll over their foreign debt. This was followed by a run on deposits in foreign branches. The absence of a lender of last resort sealed the fate of the Icelandic banks. At this stage Iceland resorted to capital controls, as Malaysia had previously done in 1998 under similar circumstances. ${ }^{2,3}$

Icelandic authorities reached an agreement with the IMF on a comprehensive financial stabilization program in November 2008 that included the introduction of capital controls. The IMF lent the government considerable amounts of foreign currency - many times the country's quota at the IMF - and oversaw the conduct of monetary and fiscal policy and the reorganization of the banking system. The IMF recommended the introduction of capital controls while keeping the current account open and allowing the interest income on domestic assets held by foreign investors to be converted into foreign currency. The Central Bank was to support the capital controls by maintaining a high policy interest rate, and it responded by raising the policy rate to $18 \%$. The combination of high interest rates and capital controls was intended to stabilize the exchange rate. Meanwhile, the automatic stabilizers of fiscal policy were allowed to have an effect. The ensuing large fiscal deficits maintained aggregate demand internally, while the capital controls and monetary policy were used to affect the exchange rate.

\footnotetext{
2 See Kaplan and Rodrik (2001) on the use of capital controls in Malaysia.
}

${ }^{3}$ For a recent survey of the macroeconomic consequences of financial crises, see Reinhart and Rogoff (2009). On sudden stops, see Calvo, Izquierdo and Loo-Kung (2006). For an account of the turmoil in Iceland, see Benediktsdottir, Danielsson, and Zoega (2011). 
This approach by the IMF was justified by stating that the high interest rate would provide a generous rate of return on financial assets held in the domestic currency, and holders of those assets would therefore be less likely to bypass the controls. However, critics pointed out those high interest rates might also create a flow of interest payments through the current account, thus lowering the exchange rate. Allowing investors to take their interest income out of the currency was meant to prevent the excessive accumulation of domestic currency assets by foreign creditors as well as maintaining credibility in international capital markets.

Gudmundsson and Zoega (2016) derive a model of exchange rate determination where the effect of a rise in interest rates on the exchange rate is ambiguous. There are basically two effects that go in opposite directions. First, higher interest rates reduce the temptation to sell local currency offshore in return for foreign currency. This effect gives a positive relationship between interest rates and exchange rates. Then there is an effect that goes in the opposite direction. A higher interest rate increases the outflow of interest payments, which makes the exchange rate depreciate. The latter effect will dominate when the level of debt is high and the monitoring of the capital controls is strong.

The argument that high interest rates may defend the value of currencies during financial crises has some, but often weak, empirical backing. Carporale, Cipollini and Demetriades (2005) came to the conclusion that tight monetary policy boosts the exchange rate in normal periods, while during crises, such as in Asia in the late 1990s, the exchange rate weakened. Goldfajn and Gupta (2003) explored whether high interest rates can increase the value of the currency following financial crises. They examined data for eighty countries that went through financial crises during the period 1980-1998. The results indicate that the interest rate had the intended effect, except when the economy was dealing with banking crises on top of a financial crisis. Finally, Flood and Jeanne (2005) developed a model that demonstrates the difficulty of using interest rate policy to affect exchange rates in a fixed exchange rate regime when fiscal deficits are large, because high interest rates have a negative effect on the public finances and consequently weaken the currency. Gudmundsson and Zoega (2016) study Iceland's experience with capital controls, and estimate a VECM in interest and exchange rates. They find that an interest rate increase makes the currency appreciate, although this effect is weak and barely statistically significant due to the weakness of the coefficient estimates in the VECM. This stands in contrast to the years of free capital movements when the short term impact of higher interest rates on the exchange rate was stronger.

\section{Interest parity condition}

The problem Icelandic authorities faced in the years following the collapse of 2008 is that investors, especially foreign investors, holding assets in domestic currency could find it in their best interest to convert their assets into foreign currency before the capital controls were lifted by circumventing the capital controls. The policy interest rate should therefore be aimed at increasing the attractiveness of holding assets in the domestic currency rather than circumventing the controls.

There is no incentive to evade capital controls when the expected return from keeping the assets in domestic currency is equal to the expected return from converting these assets 
into foreign currency offshore, buying bonds in the foreign currency, and then later returning to the domestic currency in the onshore market. The equilibrium is described by the following equation:

$$
i_{t}=i_{t}^{*}+\log \left(E_{t+1}^{e}\right)-\log \left(e_{t}\right)+p_{t}
$$

Where the returns on assets remaining in the domestic currency are represented by the interest rate $i$, which is equal to the returns on exiting the currency offshore at exchange rate $e_{t}$ - defined as the price of foreign currency - and investing in foreign assets, which yield the interest rate $i^{*}$ and then entering the domestic currency again in the future at the expected onshore exchange rate $E_{t+1}^{e_{t+1}}$. When investors require a risk premium on domestic assets the rate of return to holding domestic bonds - the left-hand side of the equation above - has to exceed the expected rate of return from leaving the domestic currency and then returning with the foreign rate of interest - by a risk premium $p$ on holding assets in domestic currency. The risk premium could be measured by the CDS on government debt, which is a measure of the probability of default. An alternative and complementary interpretation of the term $p$ in equation (1) is that domestic currency assets have less liquidity with capital controls and therefore require a higher rate of return.

Raising the domestic interest rate $i$ increases the expected return of domestic currency assets and should have the effect of raising both the onshore and the offshore exchange rate until the expected return from exiting the currency offshore equals the domestic currency interest rate, adjusted for the risk premium. ${ }^{4}$ When this equality holds, investors have no incentive to attempt to evade the capital controls. In effect, a higher domestic interest rate will reduce the supply of ISK in the offshore market, raising the offshore exchange rate, which then induces exporters to sell their foreign currency on the onshore market, raising that exchange rate too. Raising the foreign interest rate $i^{*}$ would have the opposite effect of lowering both exchange rates.

However, when capital controls are effectively used, the expected rate of return to holding domestic and foreign assets do not have to be equal and equation (1) no longer holds. Thus domestic interest rates can be lowered without lowering the onshore and the offshore exchange rate. There is also a second effect to consider, as described in a paper by Gudmundsson and Zoega (2016). When trapped foreign investors convert their interest income in domestic currency into foreign currency in the onshore market, the exchange rate will fall. This is the transfer problem first explained by Keynes in 1929. The net effect of changes in interest rates on the exchange rate is made up of these two effects; the effect of higher interest rates that may reduce leakages by increasing the rate of return from holding domestic currency assets - this will increase the onshore exchange rates, and the second effect of higher interest rates in raising the outflow of interest income - which will lower the onshore exchange rate. The first effect is likely to dominate when the level of debt held by foreigners is low and the enforcement of capital controls weak, while the latter effect dominates when the level of debt is high and capital controls are strongly enforced.

\footnotetext{
${ }^{4}$ See figure with onshore and offshore exchange rate in an appendix.
} 


\section{Event study of interest rate changes}

The experiment we wish to carry out is to explore if changes in the Central Bank's policy interest rate affect the exchange rate of the Icelandic krona. We conducted an event study where the average level of the exchange rate before and after an interest rate decision is compared, and the difference explained by interest rate changes.

Equation (1) implies that an unexpected increase in interest rates makes the exchange rate appreciate. We ran multiple least-squares regressions with the relative change of the average exchange rate - from before the interest rate decision to after - as the dependent variable and either actual changes in interest rate or unexpected changes as the independent variable. ${ }^{5}$ The unexpected change is measured by the difference between the actual policy interest rate and the forecasts carried out by the research departments of two local commercial banks, Islandsbanki and Landsbanki.

In our study, we report estimates for three sample periods. The first goes from January 2009 to August 2015. This is our whole sample and we have observations on interest rates, exchange rates and expected interest rate changes by one of the commercial banks, Islandsbanki, for this period. The second sample starts in November in 2010 and ends in August 2015. It starts later because the second commercial bank, Landsbanki, did not publish its forecast of interest rate changes until November 2010.

Two structural breaks may have occurred in the data since the beginning of 2009 . First, there was the strengthening of the monitoring controls in November 2009. From January 2009 to October 2009 the capital controls were not effectively enforced. We include a dummy variable for the months preceding November 2009 to test for a different effect of interest rates on exchange rates during this period. Our second sample does not include the year 2009 and hence can be used as a comparison to the longer sample to test for the effect of the strengthening of capital controls. Secondly, the Central Bank started to use currency market interventions as a policy tool in the spring of 2013. This has reduced fluctuations in the rate ever since. An unexpected interest rate increase would then be expected to make the Central Bank buy more foreign currency instead of seeing the exchange rate appreciate. Our third sample ends in December 2012 in order to remove the influence of this change in the use of monetary policy tools.

Figure 1 has linear graphs of the raw data for the whole sample. As the reader may note, the level of policy interest rate has become more stable in recent years and the forecasts have improved. Fluctuations in the rate of change of the exchange rate have also decreased. One explanation might be that the Central Bank tightened the capital controls in November 2009 in order to discourage those trying to withdraw domestic monetary assets from doing so. Another, and more plausible reason, is that the Central Bank managed to stabilize the exchange rate through its currency interventions.

${ }^{5}$ The exchange rate is measured by the general exchange rate index reported by Landsbanki Islands. Data on policy interest rates comes from the Central Bank of Iceland. 

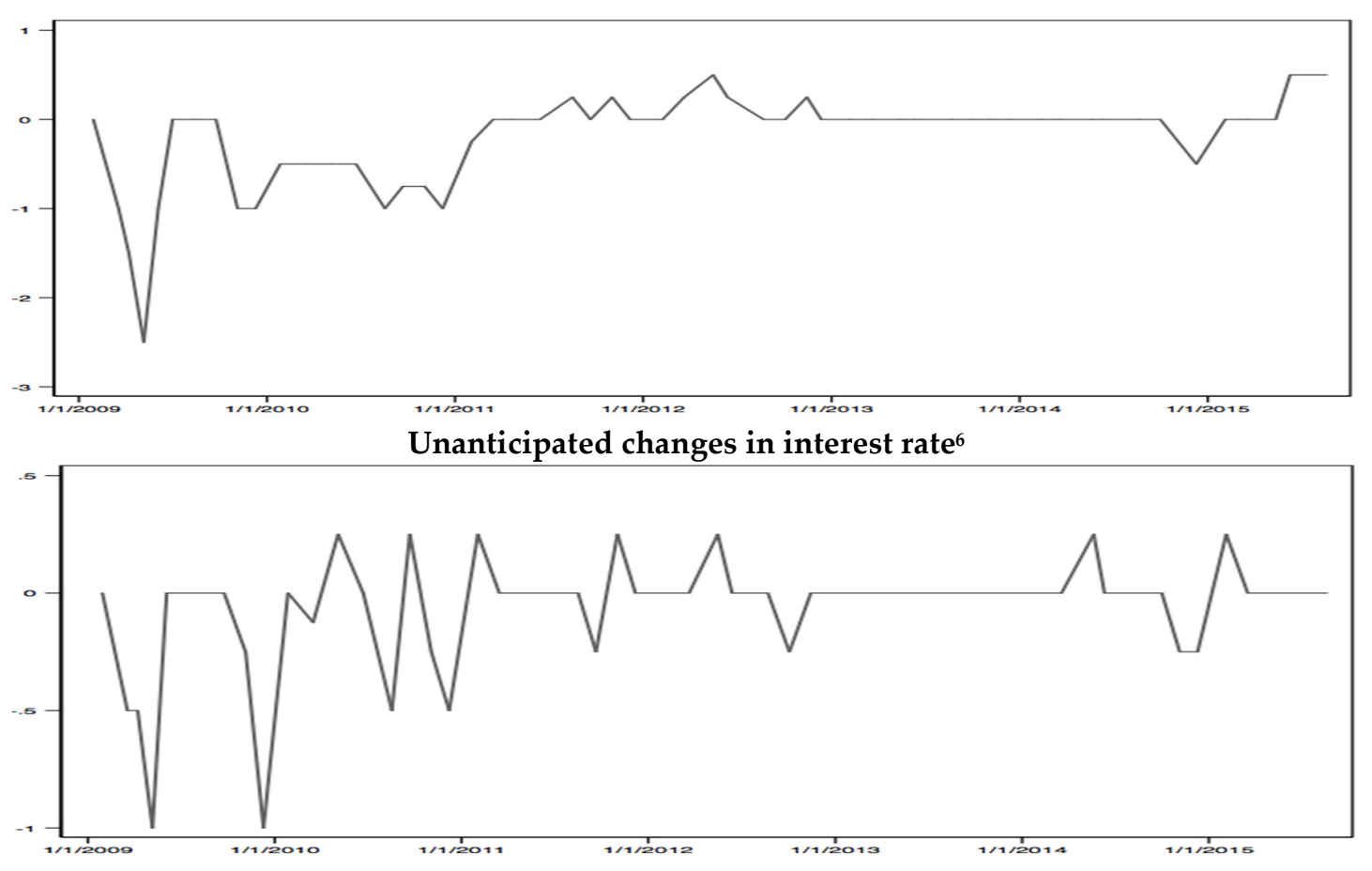

Relative difference in average exchange rate one week before and after

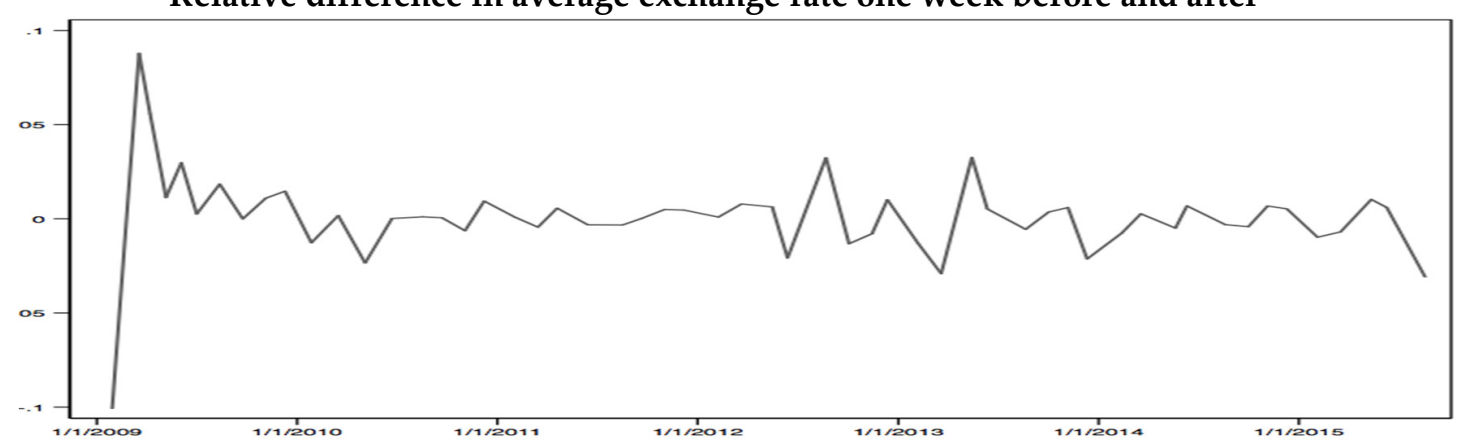

Relative difference in average exchange rate four weeks before and after

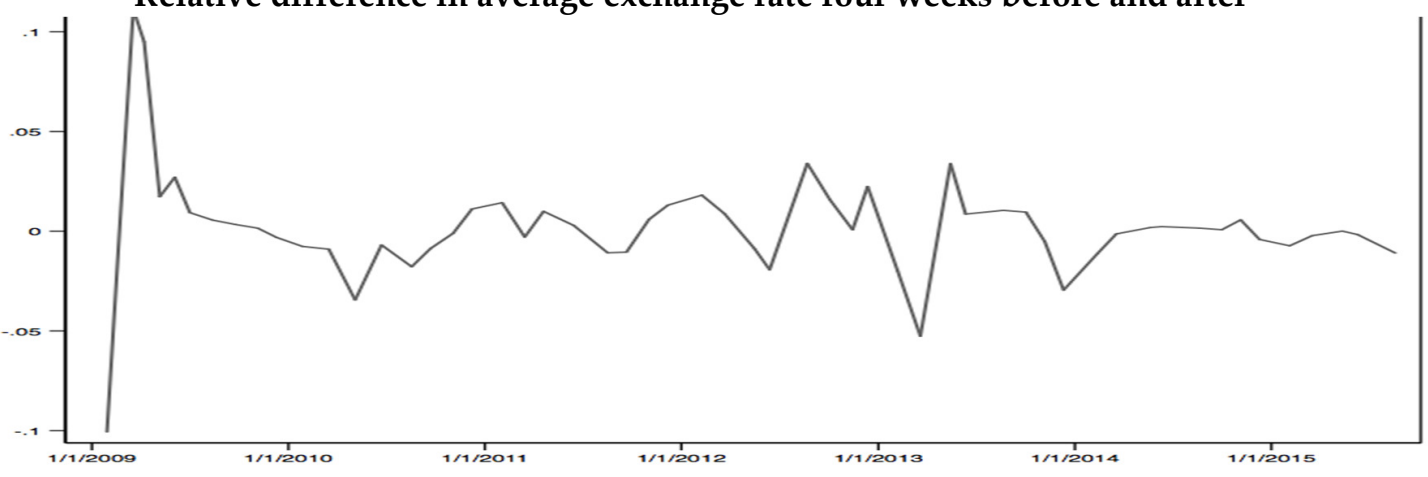

Figure 1. Difference in policy interest rate and relative difference in exchange rates Change in interest rate

${ }^{6}$ Measured by Islandsbanki's research division. 
In Tables 1 and 2 below, we present the results of the regressions mentioned above. The estimated equation in the first column of both tables is:

$$
\frac{\bar{E}_{a}-\bar{E}_{b}}{\bar{E}_{b}}=a_{o}-a_{1}\left(i_{a}-i_{b}\right)
$$

where $\bar{E}_{a}$ represents the average exchange rate after the change in policy interest rate and $\bar{E}_{b}$ the average exchange rate before the change. The policy interest rate after and before the announced day of adjustment are written as $i_{a}$ and $i_{b}$ respectively. We also use the unexpected rather than actual changes in interest rate. Here the estimated equation is

$$
\frac{\bar{E}_{a}-\bar{E}_{b}}{\bar{E}_{b}}=a_{o}-a_{1}\left[\left(i_{a}-i_{b}\right)-\left(i_{a}^{e}-i_{b}\right)\right]
$$

where $i_{a}^{e}$ stands for the forecast made by either Islandsbanki or Landsbanki. We provide the scatter plots in an appendix.

The first two columns of Table 1 reports the results of regressions for the period 1st of January 2009 to the 31st of August 2015. We first regress the change in the weekly exchange rate on the actual change in the interest rate and find that raising the policy rate by $1 \%$ (that is 100 basis points) makes the exchange rate appreciate by $1.5 \%$. The coefficient is statistically significant. In the second column we interact the interest rate change with a dummy for the months preceding the strengthening of the monitoring of the capital controls in November 2009 and find that the significance of the interest rate change stems from these months in 2009 when the monitoring of capital controls was lax.

In the third column we replace the actual change of interest rates by the unexpected change (when the expectations of Islandsbanki are used) and find that an unexpected 1\% increase in interest rates makes the exchange rate appreciate by $2.9 \%$ but this is again caused by the inclusion of 2009 in the sample. When a dummy variable for JanuaryNovember 2009 is included, in column 4, we find that a 1\% increase makes the exchange rate appreciate by $4.5 \%$ in 2009 but the effect is insignificant in the following years.

In columns 5 to 8 we use four-week averages of exchange rates and the results are quite similar to what we get in columns 1 to 4 . The effect of an unexpected interest rate increase appears to be stronger before November 2009 and weaker in the years that followed. Thus an unexpected $1 \%$ increase of interest rates makes the exchange rate appreciate by $7.7 \%$ in 2009 but the effect is insignificant from zero thereafter.

In Table 2 we use the expected interest rate changes published by Landsbanki, as well as by Islandsbanki, starting on 1 November 2010. In this case there is no interaction term for 2009. We find that both actual and unexpected changes in interest rates have a statistically insignificant effect on exchange rates. When we let the sample end in December 2012, to remove the period from January 2013-2015 when the central bank used currency market interventions to stabilize the exchange rate, we also find an insignificant effect as shown in columns 3 and 4 .

The results in the two tables can be summarized as showing that when the monitoring of the capital controls is lax, as was the case in 2009 until November of that year, an increase of interest rates could be expected to strengthen the currency holding all other factors constant but that the effective enforcement of capital controls weakened the 
relationship between exchange rates and interest rates. Therefore, the moderate change in interest rates seen in 2010-2015 did not affect the exchange rate perceptively. However, we should note that the situation in 2009 was rather fluid following the systemic collapse of the banking system in October 2008, so that other factors than the lowering of interest rates may have been affecting the exchange rate. For example, the outflow of interest payments must have been significant at the very high interest rates putting downward pressure on the exchange rate. Therefore, the estimated coefficients of the product of the time dummy for 2009 and the interest rate change in Table 1 should be taken as being indicative of a possible effect of interest rate changes on the exchange rate. 
Table 1. Effect of changes in interest rates on the exchange rate - longer sample

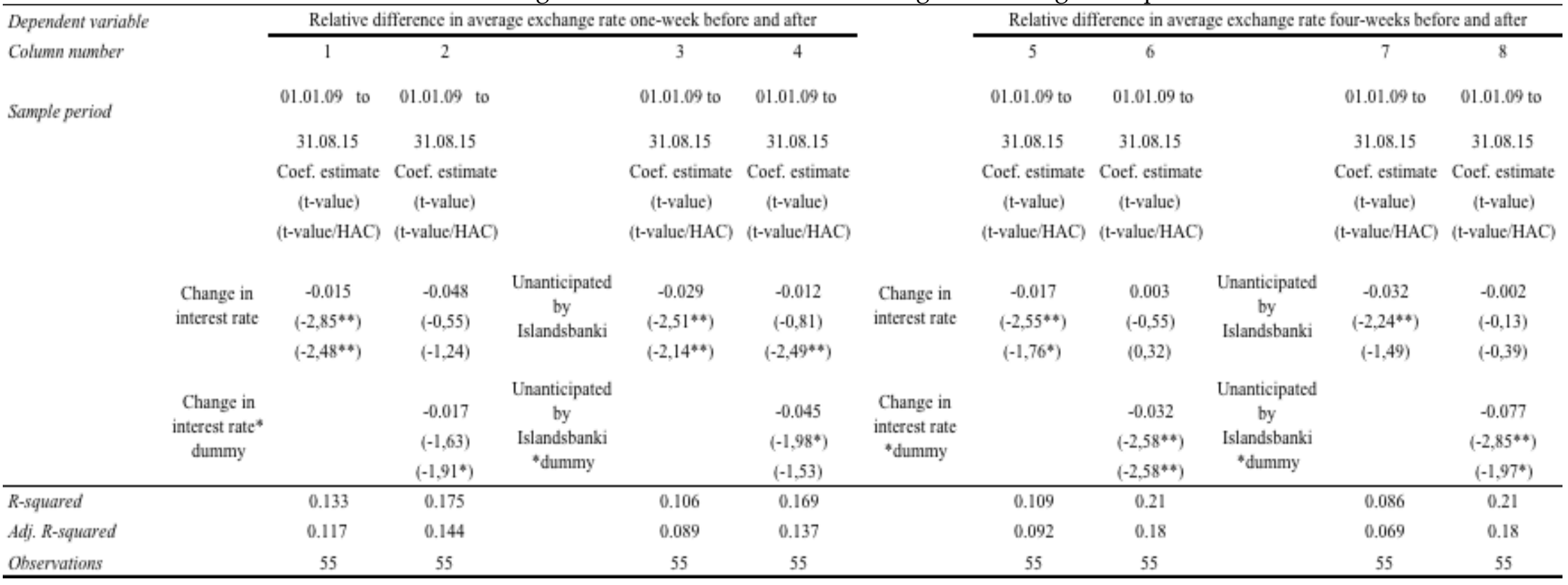

Column 1 has the results of a regression of changes in the weekly average of the exchange rate index on the change in the policy rate. In column 2 we add the interaction of a time dummy for January 2009 to October 2009 and the interest rate change to test for a different effect in 2009 before capital controls were strengthened. In column 3 we replace the change in the policy rate with the unexpected change in the policy rate, using the forecast of the Islandsbanki as a measure of expected changes. In column 4 we again introduce the interaction with the time dummy. The analysis is repeated in columns 5,6,7 and 8 using four-week averages instead of the one-week average. $\left(^{* * *}\right)$ denotes the $1 \%$ level of significance, $\left({ }^{* *}\right)$ denotes the $5 \%$ level of significance, and $(*)$ denotes the $10 \%$ level of significance. The t-value/HAC reports t-statistics based on heteroskedasticity and autocorrelation (HAC) consistent standard errors OLS estimate. 
These results suggest that using interest rates to stabilize a currency is more effective when capital controls are weakly implemented, but that the need to maintain high interest rates diminishes when the capital controls are more strongly reinforced. At least moderate changes in interest rates do not appear to affect the exchange rate with effectively enforced capital controls. However, we cannot conclude anything about what would have happened to exchange rates if the interest rates had been changed more or brought down to very low levels based on this evidence. The main conclusion of the analysis remains, which is the weak or absent effect of moderate interest rate changes in the presence of capital controls over the period 2009-2015.

Table 2. Effect of changes in interest rates on the exchange rate - shorter sample

\begin{tabular}{lcccc}
\hline \multirow{2}{*}{ Dependent variable: } & \multicolumn{4}{c}{ Relative difference in average exchange rate one-week before and } \\
\cline { 2 - 5 } Column number & 1 & 2 & 3 & 4 \\
\cline { 2 - 5 } Sample period & 1.11 .10 & 1.11 .10 & 1.11 .10 & 1.11 .10 \\
& 31.08 .15 & 31.08 .15 & 31.12 .12 & 31.12 .12 \\
& Unanticipated & Unanticipated & Unanticipated & Unanticipated \\
& by Landsbanki & by Islandsbanki & by Landsbanki & by Islandsbanki \\
Coefficient estimate & $-0,741$ & $-0,004$ & $-0,967$ & 0,006 \\
(t-value) & $(-0,66)$ & $(-0,32)$ & $(-0,73)$ & $(-0,43)$ \\
(t-value/HAC) & $(-1,42)$ & $(-0,58)$ & $(-1,10)$ & $(0,63)$ \\
\hline R-squared & 0,012 & 0,003 & 0,032 & 0,011 \\
Adj. - -squared & $-0,015$ & $-0,002$ & $-0,028$ & $-0,05$ \\
Observations & 39 & 39 & 18 & 18 \\
\hline
\end{tabular}

Columns 1 and 2 show the results of a regression of the change in the one-week average of exchange rates and the unanticipated change of interest rates from 1 . November 2010 to 31 . August 2015 while the sample used in columns 3 and 4 ends on 31. December 2012. $\left(^{* * *}\right)$ denotes the $1 \%$ level of significance, $\left({ }^{* *}\right)$ denotes the $5 \%$ level of significance, and $\left({ }^{*}\right)$ denotes the $10 \%$ level of significance. $\left.{ }^{* *}\right)$.The t-value/HAC reports t-statistics based on heteroskedasticity and autocorrelation (HAC) consistent standard errors OLS estimate.

In order to test for heteroskedasticity we ran a Breusch-Pagan test, where the null hypothesis is that the error terms in the model are independently and identically distributed. The null was rejected at the $5 \%$ level of significance for the regressions reported in columns 1 , 2, 35 and 7 in Table 1 and at the 1\% level in columns 4,6 and 8. It could not be rejected for any estimation in Table 2. This test assumes that the residuals are normally distributed. We therefore applied a test for normality based on the sample moments, which tests whether the skewness and kurtosis of the variables is consistent with the normal distribution. ${ }^{7}$ The null hypothesis is that the residuals are normally distributed and the alternative that they are nonnormally distributed. The null hypothesis was rejected for every estimation at the $1 \%$ level of significance, except for unanticipated changes in interest rates measured by Landsbanki shown in the second column of Table 2. This throws doubt on the results of the Breusch-Pagan

\footnotetext{
7 The test in question is carried out by that Stata command sktest, which implements a test as described by D'agostino, R. B., Belanger, A., \& D'agostino Jr, R. B., (1990) with empirical corrections by Royston, P. (1991).
} 
test. Therefore, we turned to the White test as it doesn't require normality. The null hypothesis of the White test is that the residual variance in a regression model is constant, i.e. the null hypothesis is that the residuals are homoskedastic. We cannot reject the null for any of the estimations in Table 1, indicating the absence of heteroscedasticity. Finally, using heteroskedasticity and autocorrelation (HAC) consistent standard errors gives t-statistics, reported in both tables, that are broadly consistent with our original results. Finally, a nonparametric alternative to the paired Student's $t$ test, the Wilcoxon signed-rank test, cannot reject the null hypothesis that interest rate do not affect exchange rates in every case at the $5 \%$ level but does reject the null that unexpected changes had no effect on the exchange rate at the $10 \%$ level of significance.

\section{Conclusions}

The historical financial crisis in Iceland provides excellent testing grounds for the effect of high interest rates accompanied by capital controls. Starting from a policy rate of $18 \%$ in February 2009 , a sequence of interest rate reductions brought interest rates down to $4.25 \%$ at the end of 2011.

Overall, the experience suggests a possible effect of moderate changes in interest rates on the exchange rate when capital controls are not enforced but the absence of a statistically significant effect when they are enforced. It follows that cutting interest rates from a very high level is not likely to make a currency depreciate in an effective capital control regime, highlighting the importance of the effective enforcement of the controls. The results are consistent with the results of the estimation of a VECM by Gudmundsson and Zoega (2016).

This paper ends with the caveat that even if small changes in the Central Bank policy rate do not affect the exchange rate notably in a capital controls regime, interest rate policy can be used to affect aggregate demand, the incentives to save and invest in a balance of payments crisis and the incentive to deleverage. Therefore, maintaining non-zero interest rates in a capital control regime may be justified by other factors. Besides, we do not know what would have happened to exchange rates in Iceland if interest rates had been brought down to very low levels in large steps, only that the small changes in interest rates that we see in the data did not affect the exchange rate in a statistically significant way once capital controls were more strongly reinforced.

\section{References}

Benediktsdottir, S., Danielsson, J., Zoega, G., (2011). Lessons from a collapse of a financial system. Economic Policy. 26 (66), 183-235.

Calvo, G., Izquierdo, A., Loo-Kung, R., (2006). Relative price volatility under sudden stops: The relevance of balance sheet effects. Journal of International Economics. 9 (1), 231-254.

Caporale, G.M., Cipollini, A., Demetriades, P.O., (2005). Monetary policy and the exchange rate during the Asian crisis: Identification through heteroscedasticity. Journal of International Money and Finance. 24 (1), 39-53.

D'Agostino, R.B., Belanger, A., \& D'Agostino Jr, R. B., (1990). A suggestion for using powerful and informative tests of normality. The American Statistician, 44(4), 316-321.

Flood, R.P., Jeanne, O., (2005). An interest rate defense of a fixed exchange rate? Journal of International Economics. 66 (2), 471-484. 
Goldfajn, I., Gupta, P., (2003). Does monetary policy stabilize the exchange rate following a currency crisis?. IMF Staff Papers. 50 (1), 90-114.

Gudmundsson, G. S. and Zoega, G., (2016). A double-edged Sword: High interest rates in capital control regimes. Economics Discussion Papers, No 2016-3, Kiel Institute for the World Economy. http://www.economics-ejournal.org/economics/ discussionpapers/2016-3.

Kaplan, E., \& Rodrik, D., (2001). Did the Malaysian capital controls work? (No. w8142). National Bureau of Economic Research.

Keynes, J.M. (1929). The German transfer problem. The Economic Journal, 39 (153), 1-7.

Reinhart, C. M., \& Rogoff, K. S., (2009). The aftermath of financial crises (No. w14656). National Bureau of Economic Research.

Royston, P. (1991). Estimating departure from normality. Statistics in Medicine, 10(8), 12831293.

\section{Data}

Data on central bank interest rate are taken from the Central Bank of Iceland's website: www.sedlabanki.is.

Data on exchange rates were taken from the website of the Landsbanki:

https://www.landsbankinn.is/markadir/gjaldmidlar/gengisthroun/\#/A/01-12-2012/18-092015/GVT-ISK/

Predicted interest rate changes were provided by the research divisions of the two commercial banks:

Islandsbanki - Department of analysis (2015)

Landsbanki Islands - Department of analysis (2015) 


\section{Appendix}

Figures A1 and A2 show the relationship between the relative change of the exchange rate (vertical axis) and the change in interest rates (horizontal axis) using one-week average in Figure A1 and four week averages in Figure A2.
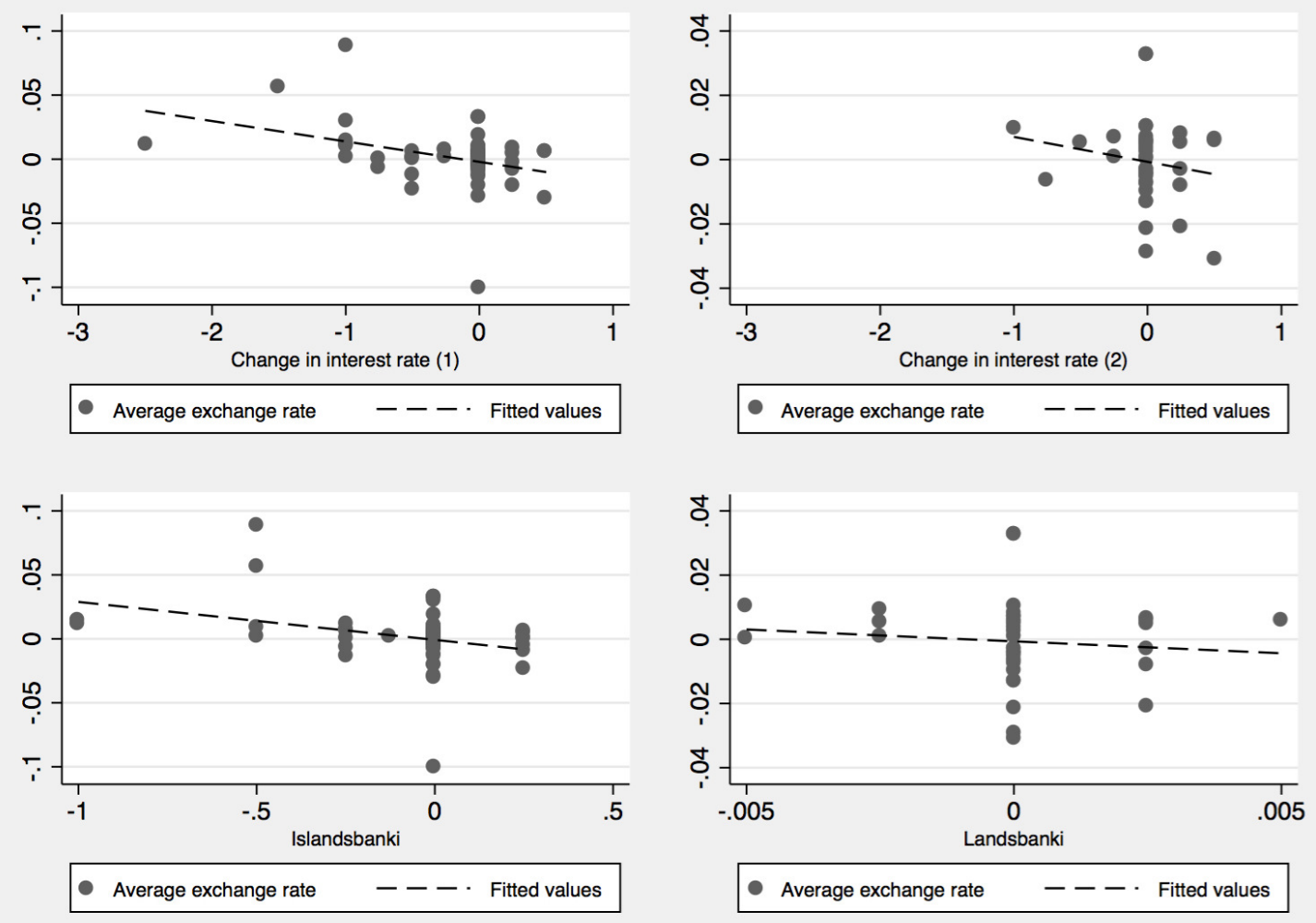

Figure A1. Changes in exchange rates (one-week average) and interest raters

The panel in the top-left corner shows the relationship between relative changes in average exchange rates using one-week averages and changes in interests for the period 1. January 2009 to 31. August 2015. The one in the top-right corner uses data from the period 1. November 2010 to 31. August 2015. The graphs below replace actual with unexpected interest rate changes for the same periods. 

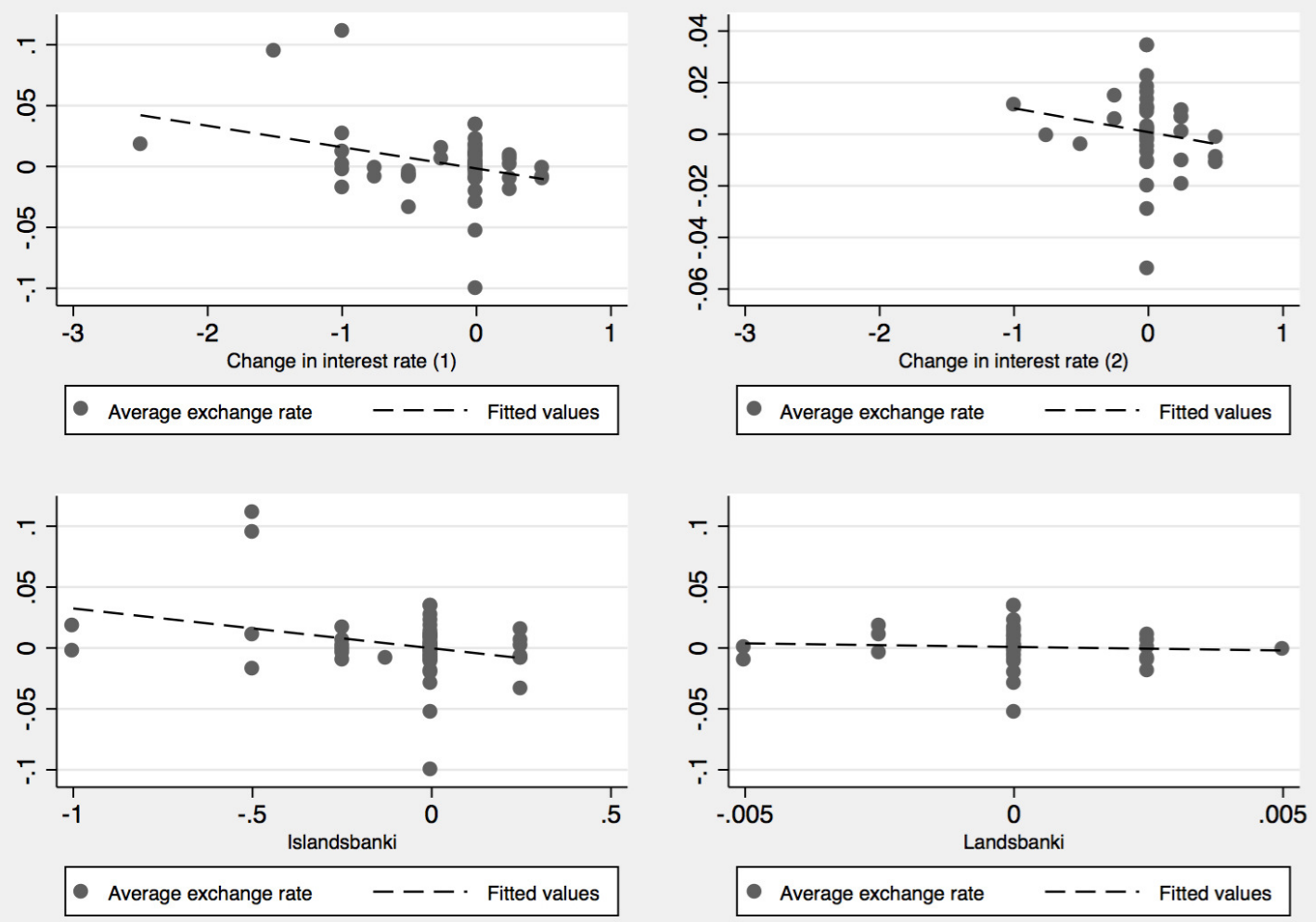

Figure A2. Changes in exchange rates (four-week average) and interest raters

The panel in the top-left corner shows the relationship between relative changes in average exchange rates using four-week averages and changes in interests for the period 1. January 2009 to 31. August 2015. The one in the top-right corner uses data from the period 1. November 2010 to 31. August 2015. The graphs below replace actual with unexpected interest rate changes for the same periods. 


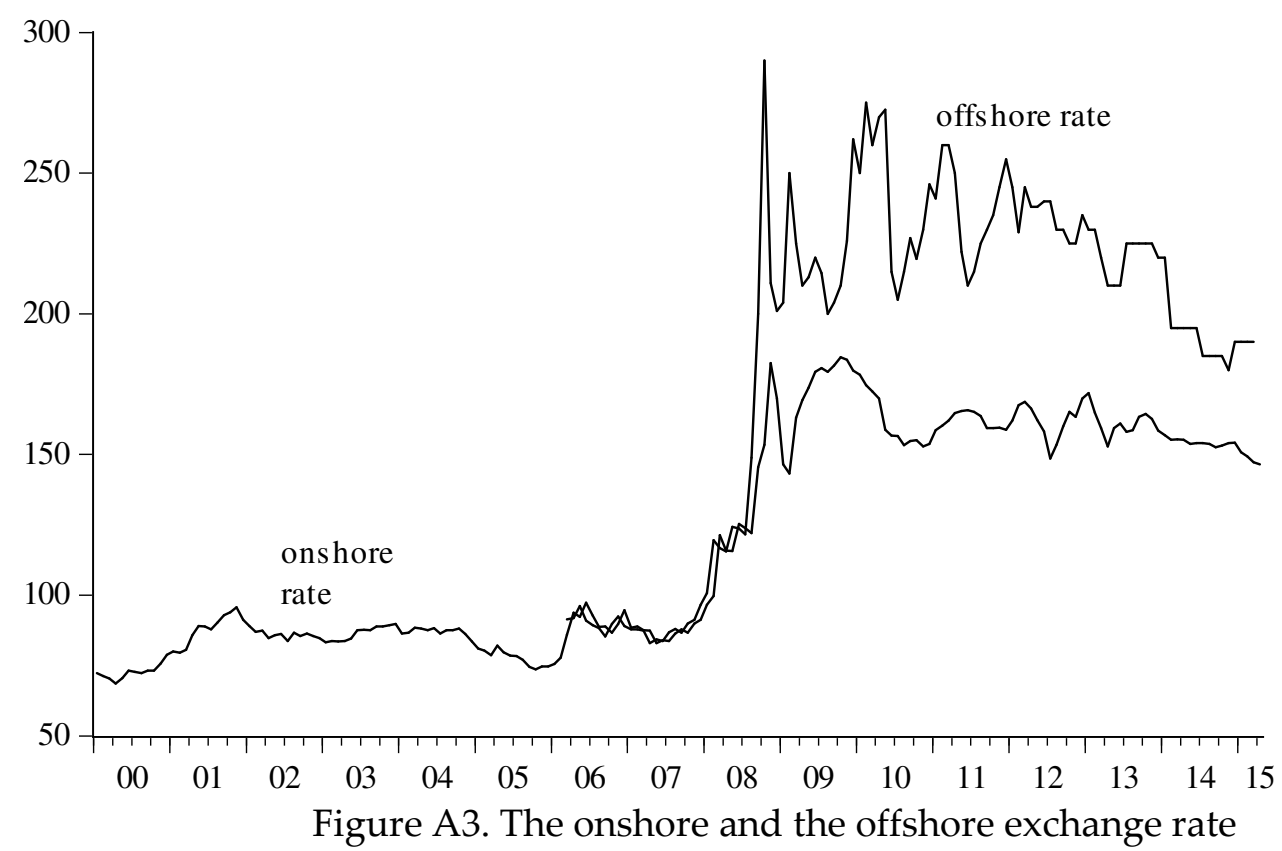


Table A1. Dataset

\begin{tabular}{|c|c|c|c|c|c|}
\hline $\begin{array}{c}\text { Table A1. } \\
\text { Dataset } \\
\text { Date }\end{array}$ & $\begin{array}{l}\text { Relative } \\
\text { diff. in } \\
\text { average } \\
\text { exchange } \\
\text { rate four } \\
\text { weeks } \\
\text { before and } \\
\text { after }\end{array}$ & $\begin{array}{c}\text { Relative } \\
\text { diff. in } \\
\text { average } \\
\text { exchange } \\
\text { rate one } \\
\text { week before } \\
\text { and after }\end{array}$ & $\begin{array}{l}\text { Change in } \\
\text { interest rate }\end{array}$ & $\begin{array}{l}\text { Unanticipated } \\
\text { change by } \\
\text { Islandsbanki }\end{array}$ & $\begin{array}{l}\text { Unanticipated } \\
\text { change by } \\
\text { Landsbanki }\end{array}$ \\
\hline 29.1 .2009 & $-0,10062$ & $-0,10069$ & 0 & 0 & N/A \\
\hline 19.3.2009 & 0,11123 & 0,08787 & -1 & $-0,5$ & N/A \\
\hline 8.4 .2009 & 0,09496 & 0,05575 & $-1,5$ & $-0,5$ & N/A \\
\hline 7.5.2009 & 0,01730 & 0,01129 & $-2,5$ & -1 & N/A \\
\hline 4.6.2009 & 0,02705 & 0,02976 & -1 & 0 & N/A \\
\hline 2.7.2009 & 0,00931 & 0,00253 & 0 & 0 & N/A \\
\hline 13.8 .2009 & 0,00559 & 0,01843 & 0 & 0 & N/A \\
\hline 24.9.2009 & 0,00341 & $-0,00004$ & 0 & 0 & N/A \\
\hline 5.11 .2009 & 0,00155 & 0,01095 & -1 & $-0,25$ & N/A \\
\hline 10.12 .2009 & $-0,00311$ & 0,01464 & -1 & -1 & N/A \\
\hline 27.1 .2010 & $-0,00763$ & $-0,01272$ & $-0,5$ & 0 & N/A \\
\hline 17.3.2010 & $-0,00900$ & 0,00170 & $-0,5$ & $-0,125$ & N/A \\
\hline 5.5 .2010 & $-0,03445$ & $-0,02344$ & $-0,5$ & 0,25 & N/A \\
\hline 23.6 .2010 & $-0,00691$ & 0,00016 & $-0,5$ & 0 & N/A \\
\hline 18.8 .2010 & $-0,01779$ & 0,00105 & -1 & $-0,5$ & N/A \\
\hline 22.9.2010 & $-0,00870$ & 0,00056 & $-0,75$ & 0,25 & N/A \\
\hline 3.11 .2010 & $-0,00105$ & $-0,00634$ & $-0,75$ & $-0,25$ & 0 \\
\hline 8.12 .2010 & 0,01115 & 0,00942 & -1 & $-0,5$ & $-0,0025$ \\
\hline 2.2 .2011 & 0,01430 & 0,00087 & $-0,25$ & 0,25 & 0 \\
\hline 16.3 .2011 & $-0,00294$ & $-0,00444$ & 0 & 0 & 0 \\
\hline 20.4 .2011 & 0,00996 & 0,00565 & 0 & 0 & 0,0025 \\
\hline 15.6 .2011 & 0,00290 & $-0,00321$ & 0 & 0 & 0 \\
\hline 17.8 .2011 & $-0,01080$ & $-0,00331$ & 0,25 & 0 & 0,0025 \\
\hline 21.9 .2011 & $-0,01050$ & 0,00019 & 0 & $-0,25$ & $-0,005$ \\
\hline 2.11 .2011 & 0,00593 & 0,00495 & 0,25 & 0,25 & 0,0025 \\
\hline 7.12 .2011 & 0,01307 & 0,00464 & 0 & 0 & 0 \\
\hline 8.2 .2012 & 0,01808 & 0,00091 & 0 & 0 & $-0,0025$ \\
\hline 21.3 .2012 & 0,00879 & 0,00787 & 0,25 & 0 & 0 \\
\hline 16.5.2012 & $-0,00881$ & 0,00633 & 0,5 & 0,25 & 0,0025 \\
\hline 13.6 .2012 & $-0,01930$ & $-0,02081$ & 0,25 & 0 & 0,0025 \\
\hline 22.8 .2012 & 0,03396 & 0,03238 & 0 & 0 & 0 \\
\hline 3.10 .2012 & 0,01579 & $-0,01325$ & 0 & $-0,25$ & 0 \\
\hline 14.11 .2012 & 0,00072 & $-0,00790$ & 0,25 & 0 & 0,0025 \\
\hline 12.12 .2012 & 0,02236 & 0,01011 & 0 & 0 & 0 \\
\hline 6.2 .2013 & $-0,02012$ & $-0,01308$ & 0 & 0 & 0 \\
\hline 20.3 .2013 & $-0,05262$ & $-0,02909$ & 0 & 0 & 0 \\
\hline 15.5 .2013 & 0,03386 & 0,03254 & 0 & 0 & 0 \\
\hline 12.6 .2013 & 0,00859 & 0,00524 & 0 & 0 & 0 \\
\hline 21.8 .2013 & 0,01046 & $-0,00558$ & 0 & 0 & 0 \\
\hline 2.10 .2013 & 0,00959 & 0,00360 & 0 & 0 & 0 \\
\hline 6.11 .2013 & $-0,00519$ & 0,00598 & 0 & 0 & 0 \\
\hline 11.12 .2013 & $-0,02954$ & $-0,02131$ & 0 & 0 & 0 \\
\hline 12.2 .2014 & $-0,01119$ & $-0,00762$ & 0 & 0 & 0 \\
\hline 19.3 .2014 & $-0,00135$ & 0,00266 & 0 & 0 & 0 \\
\hline 21.5 .2014 & 0,00184 & $-0,00494$ & 0 & 0,25 & 0 \\
\hline 11.6 .2014 & 0,00231 & 0,00685 & 0 & 0 & 0 \\
\hline 20.8 .2014 & 0,00156 & $-0,00312$ & 0 & 0 & 0 \\
\hline 1.10 .2014 & 0,00075 & $-0,00417$ & 0 & 0 & 0 \\
\hline 5.11 .2014 & 0,00568 & 0,00679 & $-0,25$ & $-0,25$ & 0 \\
\hline 10.12 .2014 & $-0,00412$ & 0,00530 & $-0,5$ & $-0,25$ & $-0,0025$ \\
\hline 4.2 .2015 & $-0,00731$ & $-0,00978$ & 0 & 0,25 & 0 \\
\hline 18.3 .2015 & $-0,00221$ & $-0,00696$ & 0 & 0 & 0 \\
\hline 13.5 .2015 & 0,00005 & 0,01027 & 0 & 0 & $-0,005$ \\
\hline 10.6 .2015 & $-0,00167$ & 0,00604 & 0,5 & 0 & 0,005 \\
\hline 19.8 .2015 & $-0,01091$ & $-0,03085$ & 0,5 & 0 & 0 \\
\hline
\end{tabular}

